\title{
ASUMSI PUBLIK TERHADAP PASAL 51 KITAB UNDANG-UNDANG HUKUM PIDANA SEBAGAI DASAR IMUNITAS PEJABAT NEGARA
}

\author{
Orien Effendi \\ Program M agister IImu Syari'ah F akultas Syari'ah dan Hukum \\ Universitas Islam Negeri Sunan Kalijaga Yogyakarta \\ orieneffendi3@gmail.com
}

\begin{abstract}
Many people consider that the existence of Article 51 paragraph (1) and (2) in the Criminal Code is a basis for absolute immunity or immunity for officials. No exception for ordinary people who ultimately know the contents of the article who then assume that the law we profess is very damaging to a sense of justice. The existence of this article has also attracted the attention of academics, as evidenced by the number of studies published in publications that we can find in online media. It is this community's assumption that will lead to a setback of the law itself because of the loss of public trust in the existing legal system. Position orders without authority, do not cause criminal abolition, except if the governed, in good faith thinks that the order is given with authority and its implementation is included in the work environment, that is about the sound of paragraph (2) of article 51 of the Criminal Code. The problem that often occurs is that many articles in legislation do not explain in detail the true meaning. If we may examine paragraph (2) in that article, it means that an official's actions can be justified even though there is no prior order, either from the law or an order of an authorized position with only the basis of good faith from the act. The intent of good faith can invite diverse interpretations, then questions arise; what are the criteria of good faith, whichever boundary of good faith is intended, and so on.
\end{abstract}

Keywords: Article 51, Criminal Code, Academics, J ustice.

Abstrak, Banyak kalangan yang menilai bahwa keberadaan Pasal 51 ayat (1) dan (2) dalam KUHP adalah sebagai dasar imunitas atau kekebalan hukum absolut bagi para pejabat. Tidak terkecuali masyarakat awam yang pada akhirnya mengetahui isi daripada pasal tersebut yang kemudian beranggapan bahwa hukum yang kita anut sangatlah mencederai rasa keadilan. Keberadaan pasal tersebut selama ini juga menarik perhatian kalangan akademisi, terbukti dengan banyaknya kajian-kajian yang di publikasi yang dapat kita temui di media-media online. Asumsi masyarakat inilah yang akan menimbulkan kemunduran hukum itu sendiri sebab hilangya kepercayaan publik terhadap sistem hukum yang ada. Perintah jabatan tanpa wewenang, tidak menyebabkan hapusnya pidana, kecuali jika yang diperintah dengan itikad baik mengira bahwa perintah diberikan dengan wewenang dan pelaksanaannya termasuk dalam lingkungan pekerjaannya, begitulah kira-kira bunyi dari Ayat (2) Pasal 51 KUHP. Permasalahan yang sering terjadi adalah banyaknya pasalpasal dalam perundang-undangan tidak menjelaskan secara terperinci akan makna sesungguhnya. Jika kita boleh menelaah Ayat (2) dalam pasal tersebut, itu berarti suatu tindakan pejabat dapat dibenarkan meskipun tidak ada perintah sebelumnya, baik dari undang-undang ataupun perintah jabatan yang berwenang dengan hanya di dasari adanya itikad baik dari tindakan itu. Maksud dari itikad baik dapat mengundang penafsiran yang beragam, lalu pertanyaan 
yang muncul; apa kriteria itikad baik tersebut, mana saja batasan itikad baik yang dimaksud, dan lain sebagainya.

Kata Kunci: Pasal 51, KUHP, Akademisi, Keadilan.

\section{Pendahuluan}

Adanya asumsi publik terhadap keberadaan Pasal 51 Ayat (1) dan (2) Kitab Undang-Undang Hukum Pidana (KUHP) sebagai asas imunitas atau kekebalan hukum bagi pejabat negara tidak terlepas dari keberadaan pasal tersebut yang di mana jika secara sekilas dilihat memang bisa terjadi penafsiran yang beragam, sebagaimana bunyi ketentuan Pasal 51 Ayat (1) KUHP bahwa apabila seseorang melakukan suatu perbuatan untuk melaksanakan perintah jabatan yang berwenang maka tidak dapat dipidana. Ketentuan dalam pasal ini secara sepintas memang bisa menimbulkan penfasiran, semisal adanya asumsi bahwa sekalipun pemilik kewenangan yang memberikan perintah atas kepentingan dirinya maka yang menjalankan perintah tidak dapat dipidana. Asumsiasumsi ini muncul sebab bunyi pasal yang multitafsir dan sangat perlu penjelasan terperinci.

Padahal pada ketentuan Pasal 51 Ayat (2) diperjelas dengan disebutkan bahwa perintah dari jabatan yang tidak berwenang tidak akan menghapus pidana, kecuali seseorang yang diperintah dengan mengira bahwa perintah tersebut telah diberikan oleh jabatan yang berwenang dan pelaksanaannya termasuk dalam kapasitas atau lingkungan pekerjaannya. Atau dapat kita melihat ketentuan pada pasal sebelumnya yakni Pasal 50 KUHP yang menyebutkan bahwa perbuatan yang dilakukan atas dasar adanya ketentuan dalam undang-undang maka tidak dapat dipidana. Maka yang perlu kita pahami bahwa perintah dari jabatan yang berwenang tersebut harus berdasarkan ketentuan undangundang. Namun sebagaimana yang menjadi permasalahan dari munculnya asumsi publik yang menyebutkan bahwa Pasal 51 KUHP ini sebagai pasal imunitas atau kekebalan hukum bagi seorang pejabat berangkat dari penggunaan redaksi bahasa yang kalau secara sepintas untuk memaknai ketentuan kata "itikad baik" pada pasal tersebut bisa memunculkan penafsiran beragam termasuk asumsi publik yang demikian itu.

Sebagaimana halnya ketentuan Pasal 51 KUHP tersebut pernah dijadikan sebagai asas pembelaan terhadap kasus tindak pidana korupsi oleh seorang pejabat di instansi pemerintahan yang dilakukan oleh Oentarto Sindung Mawardi pada tahun 2010 yang lalu, di mana saat itu perkaranya dilimpahkan ke Pengadilan Tipikor Jakarta Selatan yang saat ini Pengadilan Tipikor sudah pindah ke Pengadilan Negeri Jakarta Pusat, perkara Oentarto tersebut terdaftar dengan nomor perkara PN Jakarta Selatan Nomor 540/Pdt.G/2010/PN.Jkt.Sel. ${ }^{1}$ Dalam kasus Oentarto Sindung Mawardi tersebut yang dituduhkan kepadanya kala itu tentang pembuatan radiogram dan penyediaan mobil pemadam kebakaran. Sebagaimana disampaikannya pada persidangan kala itu ia beralasan dalam pembelaannya yang mengatakan bahwa pembuatan radiogram dan penyediaan mobil pemadam kebakaran merupakan perintah jabatan, atau dengan kata lain

\footnotetext{
${ }^{1}$ Maya Septiani, 'Oentarto Mengaku Hanya Jalankan Perintah Jabatan”, https://m.hukumonline. com/berita/ baca/lt4b2f77e45c445/oentarto- mengaku- hanya-jalankan-perintah-jabatan/. akses 16 Juni 2020 .
} 
Oentarto kala itu menjadikan ketentuan Pasal 5I KUHP yang menurutnya dapat dijadikan sebagai asas pembenar terhadap apa yang telah dilakukannya itu karena berkaitan dengan tindakan atas perintah jabatan. Meski demikian kasus dugaan tindak pidana korupsi yang disangkakan kepadanya kala itu ia dinyatakan secara sah bersalah yang dituang dalam putusan hakim pada pengadilan tingkat pertama.

Berkaitan dengan kasus yang dipaparkan di atas, perlu kita pahami bahwa maksud dari perintah jabatan yang berwenang yang disebutkan dalam Pasal 51 Ayat (1) KUHP adalah pemberian perintah dari seorang yang memiliki jabatan yang sah atau berwenang dalam kapasitas jabatannya tersebut. Jika tidak demikian maka penggunaan Pasal 51 Ayat (1) KUHP tersebut tidak dapat dijadikan sebagai alasan atau pembelaan agar tidak terjerat kasus hukum terhadap apa yang seseorang tersebut lakukan. Dengan pengecualian perbuatannya tersebut dapat dibuktikan dan memenuhi unsur dari perbuatan atau tindakan itikad baik.

Dari kasus di atas memberikan gambaran kepada kita bahwa tidak semua perintah atasan bisa kita jadikan pembelaan terhadap kasus hukum yang sewaktu-waktu dapat menjerat kita. Atas dasar perintah sesuai peraturan perundang-undangan misalnya, itu adalah bunyi Pasal 50 KUHP kemudian dilanjutkan dalam Ayat (1) Pasal 51 KUHP di mana perintah yang dibenarkan adalah atas dasar perintah dari penguasa yang sah, begitupun dengan yang terdapat dalam lanjutan Ayat (2) Pasal 51 KUHP, tindakan diluar perintah atas itikad baik juga harus mampu dibuktikan dengan sejelas-jelasnya bahwa perbuatan yang kita lakukan adalah yang sebenarnya di kehendaki oleh nilai-nilai kebenaran atau nilai keadilan bagi masyarakat.

Berdasarkan pemaparan pada latar belakang di atas maka dapat diperjelas bahwa terdapat batasan pembahasan pada tulisan ini yang mencangkup bagaimana pandangan publik atau masayarakat luas terhadap keberadaan Pasal 51 Kitab Undang-Undang Hukum Pidana terkait dengan asumsi bahwa pasal tersebut dijadikan sebagai dasar imunitas atau hal yang seringkali menjadi alasan pembelaan para pejabat negara tatkala terjerat suatu perkara tindak pidana. Selain itu dalam tulisan ini juga akan menyinggung bagaimana terkait penafsiran hukum oleh hakim berkenaan dengan bunyi redaksi dari Pasal 51 KUHP tersebut yang seringkali dijadikan para tersangka sebagai asas pembelaan, selain itu akan dijelaskan pula bagaimana penghapusan pidana terhadap ketentuan pasal lainnya dalam KUHP.

\section{Metodologi Penelitian}

Penelitian hukum adalah kegiatan ilmiah, dasar penelitian terletak pada metode, sistematika, atau pemikiran tertentu. Di mana penelitian bertujuan untuk mengetahui gejala-gejala tertentu terhadap suatu peristiwa. Untuk mengetahui gejala-gejala tertentu tersebut maka hendaknnya memerlukan langkah-langkah seperti memeriksa fakta-fakta yang ada terhadap tema penelitian tersebut. Adapun tujuannya adalah untuk memecah permasalahan terhadap suatu permasalahan yang sedang di amati atau sedang diteliti. ${ }^{2}$ Jenis penelitian ini merupakan penelitian hukum normatif yang di mana karakter dari penelitian hukum normatif ini ialah menjabarkan sebuah kebenaran yang pada awalnya

\footnotetext{
${ }^{2}$ Soerjono, Pengantar Hukum, Jakarata: UI Press, 1984, hlm. 42.
} 
berpatokan pada asas-asas atau norma hukum. Sebagaimana kesemuanya itu penelitian yang dilakukan kali ini adalah berkaitan dengan peraturan perundang-undangan yang selaras atau bersinggungan langsung dengan tema penelitian kali ini.

Dalam tulisan kali ini melakukan pendekatan secara konseptual, yang mana merupakan suatu pendekatan penelitian yang melihat dari pandangan-pandangan atau doktrin yang terdapat dalam hukum itu sendiri. Dari kegiatan mempelajari atau menganalisa pandangan atau doktrin hukum tersebut maka nantinya akan ditemukan pengertian, konsep, asas-asas hukum dan lain sebagainya yang berkaitan dengan permasalahan yang terjadi. ${ }^{3}$ Tulisan ini adalah sebuah penelitian hukum normatif, adapun sumber penelitian ini adalah berupa bahan hukum primer dan bahan hukum sekunder. Bahan hukum primer dalam tulisan ini adalah perundang-undangan atau Pasal 51 Ayat (1) dan (2) KUHP. Sedangkan bahan sekundernya ialah berupa karya-karya tentang hukum, buku, jurnal, dan lain sebagainya yang tentunya tulisan-tulisan yang berkaitan dengan penelitian kali ini.

\section{Pembahasan}

\section{A. Pengertian Hukum Pidan Dan Ketentuan Pasal 51 KUHP}

Dalam beberapa literatur yang ada, banyak penjelasan tentang hukum pidana, di mana penjelasan hukum pidana tersebut merupakan bagian dalam bidang ilmu hukum. Dalam memahami atau mendefinisikan hukum pidana harus melihat beberapa sudut pandang yang menjadi sebuah acuan. Hukum pidana menurut Mezger ialah "sebuah aturan hukum yang mengikat terhadap suatu perbuatan yang di mana perbuatan tersebut memenuhi syarat unsur pidana". ${ }^{4}$ Selain itu, Simons juga memberikan pendapatnya mengenai hukum pidana, yang di mana ia menyebutkan bahwa, " hukum pidana mencangkup semua tindakan yang seharusnya dilakukan dan yang dilarang yang di mana dibuat oleh suatu negara atau kekuasaan yang ada. Yang di mana kemudian para pelanggarnya diberikan ancaman atau dipidana karena telah melakukan sesuatu yang mengakibatkan unsur hukum pidana tersebut terpenuhi.

Jadi kesimpulannya, hukum pidana ialah adanya suatu perbuatan yang menimbulkan syarat terpenuhinya unsur pidana, atau dengan kata lain adanya suatu perbuatan yang dilakukan yang di mana sebelumnya dilarang oleh pembuat hukum itu sendiri. ${ }^{5}$ Berkaitan dengan ketentuan pada hukum pidana tersebut semetinya anggapan atau asumsi publik terhadap keberadaan Pasal 51 KUHP tidak seharusnya kita berlebihan yang mengira bahwa pasal dalam hukum pidana tersebut adalah merupakan perlindungan atau asas kekebalan hukum bagi para pejabat. Mengingat dari kasus korupsi yang sudah disinggung sebelumnya pada tulisan ini dia atas ketika pejabat menjadikan Pasal 51 KUHP tersebut sebagai pembelaannya namun tidak dapat diterima.

\footnotetext{
${ }^{3}$ Peter Mahmud Marzuki, Penelitian Hukum, Jakarta: Prenada Media Group, 2015, hlm. 135.

${ }^{4}$ Ida Bagus Surya, Hukum Pidana Materil dan Formil, Denpasar: Udayana University Press, 2015, hlm. 2.

${ }^{5}$ Andi Sofyan dan Nur Aziza, Hukum Pidana, Makasar: Pustaka Pena Pers, 2016, hlm. 2.
} 
Asumsi publik sebagaimana disebutkan di atas yang mengira bahwa keberadaan Pasal 50, 51, Ayat (1) dan (2) KUHP tersebut sebagai asas imunitas atau kekebalan hukum bagi pejabat negara pada dasarnya tidaklah sebuah kekeliruan, karena hal itu merupakan amanat konstitusi tentang kebebasan berpendapat dan sebagainya, disisi lain itu tandannya merupakan suatu bentuk kepedulian dan kepekaan publik terhadap situasi penyelenggaraan hukum.

\section{B. Asumsi Publik Tentang Adanya Pasal Imunitas Atau Kekebalan Hukum Pejabat Negara Dalam KUHP dan Batasannya}

Secara umum mengenai ketentuan imunitas pada dasarnya tidak ada penjelasan atau pernyataan yang secara langsung tertuang pada sebuah peraturan hukum khususnya pada sistem tata hukum di Indonesia terlebih dalam KUHP. Sebagaimana penyebutan kata imunitas tersebut menurut hemat penulis tidak lain adalah merupakan sebuah penyamaan makna atau penafsiran dari ketentuan Pasal 51 KUHP. Sebagaimana asumsi publik itu dengan pemahaman bahwa hak imunitas sebagai suatu kekebalan hukum terhadap seorang pejabat negara yang di mana kedudukan ataupun tugas yang telah ia lakukan itu atas nama kepentingan negara.

Dalam hemat penulis adanya asumsi terhadap keberadaan Pasal 51 KUHP ini sebagai suatu pasal imunitas bagi pejabat negara yang di mana seorang pejabat yang menjadikan ketentuan pasal ini sebagai alasan pembenar ketika mereka terjerat kasus hukum seperti disamapaikan dimuka terhadap pembelaan yang dilakukan oleh terdakwa Oentarto, pada dasarnya berangkat dari suatu fakta bahwa dalam hal kewenangan yang dimiliki seorang pejabat seringkali dihadapkan dengan peraturan normatif atau ketentuan regulasi yang begitu rumit, sehingga diberikanlah kebebasan berpendapat dan bertindak seorang pejabat tersebut yang tertuang dalam Pasal 51 KUHP yang kemudian lahirnya anggapan adanya kekebalan hukum atau ketentuan hak imunitas yang dimiliki oleh pejabat negara. ${ }^{6}$ Padahal jika melihat sebelumnya pada Pasal 50 yang berkaitan dengan Pasal 51 KUHP barangkali anggapan tentang kekebalan hukum bagi pejabat itu tidak akan pernah kita dengar, terlebih lagi jika kita memahami dengan mendalam ketentuan Pasal 51 Ayat (1) dan (2) KUHP tersebut.

Di sisi lain untuk mengatakan kekebalan hukum seperti yang diasumsikan oleh publik tersebut tidaklah semudah yang diasumsikan. Sebagaimana bahwa Pasal 50 dan Pasal 51 KUHP itu memang secara ketentuan penjabarannya disebutkan kurang lebih bahwa tidak dapatnya dituntut seorang pejabat baik secara perdata maupun pidana apabila yang telah dilakukannya berdasarkan ketentuan perundang-undangan atau dengan adanya itikad baik. Jika sekilas kita melihat ataupun memaknai ketentuan pasal yang disebutsebut sebagai pasal imunitas atau kekebalan hukum bagi pejabat, maka tidaklah keliru sebab redaksi secara bahasa memang bisa menggiring opini dengan penafsiran yang beragam.

\footnotetext{
${ }^{6}$ Atang Irawan, Hak Imunitas Pejabat Negara, https://rmol.id/amp.2020/05/01/432808/ https-rmolid-read-2020-05-01-432808-hak-imunitas-prjabat-negara. akses 26 November 2020.
} 
Namun meski demikian pemankanaan ketentuan Pasal 50 dan Pasal 51 KUHP tersebut yang disebut sebagai pasal imunitas juga seharusnya kita dapat memaknainya dengan bijak, "tindakan yang dilakukan oleh pejabat dengan mengedepankan itikad baik sesuai dengan perintah atau amanat undang-undang', pernyataan atau redaksi bahasa dalam pasal ini saja sudah jelas-jelas bahwa perbuatan yang dilakukan oleh pejabat negara tersebut tidak semerta sebagaimana kepentingan atau keinginan pribadinya, melainkann harus melihat juga ketentuan perundang-undangan dalam tindakan yang menurutnya itu merupakan tindakan itikad baik.

Dari pemaparan di atas mengenai anggapan adanya ketentuan pasal imunitas pada dasarnya secara langsung tidak disebutkan dalam peraturan perundang-undangan manapun, sebagaimana dalam Pasal 50, 51 Ayat (1) dan (2) KUHP tersebut tidak sedikitpun disebutkan pejabaran tentang ketentuan imunitas tersebut. Namun bilamana kita sependapat dengan asumsi publik tersebut terkait pemaham bahwa disitu terdapat ketentuan kekebalan hukum dan sebagainya, maka secara tidak langsung dapat kita jadikan ketentuan pada pasal lainnya dalam KUHP tersebut sebagai batasan kepada para pejabat dalam menjadikan ketentuan Pasal 50, 51 Ayat (1) dan (2) KUHP tersebut sebagai alasan ketika dihadapkan oleh suatu perkara tindak pidana yang berkaitan dengan perintah jabatan atau kewenangan lainnya.

Sebagaimana batasan-batasan itu dapat penulis sampaikan melalui penjabaran baik yang berangkat dari asumsi publik maupun menurut hemat penulis dalam memahami ketentuan yang terkandung dalam Pasal 50, 51 Ayat (1) dan (2) KUHP tersebut. Sebagaimana disebutkan sebelumnya bahwa menurut hemat penulis asumsi tersebut pada dasarnya muncul karena pemaknaan atau penafsiran bunyi redaksi bahasa terhadap keberadaan Pasal 50, 51 Ayat (1) dan (2) KUHP yang diasumsikan sebagai ketentuan perundang-undangan yang memberikan kekebalan hukum bagi seorang pejabat.

Dibawah ini akan dipaparkan batasan-batasan tentang ketentuan Pasal 50, 51 Ayat (1) dan (2) KUHP yang diasumsikan sebagai pasal imunitas. Penjelasan batasan-batasan ini berangkat dari analisa penulis terhadap asumsi publik dan pemaknaan ketentuan pasal tersebut. Batasan-batasan itu sebagai berikut:

\section{Memahami Penafsiran Hukum}

Sebagaimana disebutkan sebelumnya bahwa asumsi publik yang menganggap bahwa Pasal 50, 51 Ayat (1) dan (2) KUHP tersebut sebagai pasal imunitas atau sebuah peraturan perundang-undangan yang memberikan kekebalan hukum bagi pejabat pada dasarnya karena terjadi permasalahan dari segi pemaknaan bunyi pasal dan juga kurangnya pemahaman secara mendalam tentang pasal dalam KUHP tersebut. Maka dengan demikian melakukan upaya penafsiran atau pemaknaan sangatlat penting dalam hal ini. Disamping hal itulah yang merupakan salah satu batasan masyarakat dalam berasumsi atau batasan yang pada dasarnya perlu dicermati dalam ketentuan Pasal 51 KUHP, di mana semestinya masyarakat atau publik harus memahami lebih dalam baik dari segi penafsiran hukum dan lainnya. Dengan demikian dari kegiatan penafsiran hukum ini dapat ditemukan suatu kesimpulan bahwa pada dasarnya ketentuan Pasal 51 KUHP tersebut memiliki batasan-batasan. 
Sebagaimana halnya bahwa melakukan penafsiran hukum merupakan suatu proses atau metode yang tidak bisa terpisahkan jika kita membahas permasalahan hukum. Berkaitan dengan itu bahwa sebagai tujuan penafsiran hukum tersebut adalah untuk menggali atau menemukan maksud secara mendetail terhadap perundang-undangan yang telah dibuat. Dengan maksud bahwa langkah penafsiran hukum tersebut mampu menemukan kejelasan makna daripada undang-undang yang sudah dibuat. Demikian halnya dalam penerapan hukum pidana, di mana penafsiran hukum tersebut sudah menjadi suatu kebiasaan para penegak hukum, sebagai gambaran bahwa beberapa pasal dalam sebuah undang-undang masih banyak yang menggunakan istilah umum, atau penggunaan bahasa yang orang awam bisa saja keliru jika sepintas membacanya, sebagaimana ketentuan pada Pasal 50, 51 Ayat (1) dan (2) KUHP. Maka melakukan penafsiran hukum tersebut menjadi suatu kewajiban jika melihat permasalahan seperti itu.

Selain itu jika kita melihat urgensi daripada pemberlakuan metode penafsiran hukum terhadap permasalahan hukum, maka sudah selayaknya langkah penafsiran hukum tersebut dilakukan. Sebagai contoh, tidak jarang dalam sebuah persidangan majelis hakim seringkali melakukan penafsiran hukum, tujuannya memudahkan seseorang yang diadili maupun masyarakat pada umumnya yang menyaksikan persidangan tersebut. Sebagaimana disebutkan sebelumnya, penafsiran-penafsiran hukum tersebut meliputi pengungkapan penggunaan bahasa yang sulit dipahami agar menjadi lebih jelas, pengungkapan maksud daripada pasal-pasal yang ada, dan pengembangan suatu makna yang tidak disebutkan namun untuk mengisi kekosongan hukum. Adapun beberapa sebab perlunya langkah penafsiran hukum dalam penerapan hukum pidana yakni sebagai berikut:

a. Sifat daripada hukum tertulis yang statis atau kaku seringkali tidak dapat mengikuti arus perkembangan zaman, sebagaimana halnya seiring perkembangan zaman maka permasalahan baru seringkali bermunculan setiap zamannya. Sedangkan untuk melakukan pembaharuan atau mengamandemenkan sebuah hukum tidak bisa dilakukan setiap saat ketika kita merasa bahwa hukum tersebut sudah kadaluwarsa dan sebagainya. Akibat dari hukum yang selalu tertinggal oleh kemajuan zaman maka langkah penafsiran hukum menjadi solusi, agar hukum tersebut dapat terus dipergunakan meski adanya permaslahan baru pada saat perkembangan zaman. Selain langkah penafsiran hukum, hal ini ada keterkaitannya juga dengan penggunaan putusan hakim terdahulu atau yurisprudensi ketika terdapat kekosongan hukum pada masa perkembangan zaman seiring hukum belum diperbaharui.

b. Seringkali dalam penyusunan atau ketika hukum tersebut dibentuk, terdapat halhal yang sebelumnya tidak diatur atau tidak ditulis. Namun ketika hukum atau perundang-undangan tersebut sudah dijalankan seringkali ditemukan hal-hal yang tidak disebutkan. Maka dalam hal kekosongan hukum ini pun salah satu solusinya adalah melakukan penfasiran hukum.

c. Kadangkala dalam perumusan perundang-undangan memuat hal-hal yang bersifat umum yang tidak menjelaskan rincian daripada maksud perundang-undangan 
tersebut. Maka langkah penafsiran hukum lagi-lagi menjadi sebuah solusi dalam menghadapi permasalahan semacam itu. Adapun sebagai contoh seperti yang terdapat dalam Pasal 51 Ayat (1) dan (2) KUHP, di mana maksud dari "itikad baik" dalam pasal tersebut bersifat multitafsir atau penafsiran yang beragam jika tidak dijelaskan atau ditafsirkan oleh penegak hukum yang berwenang, seperti majelis hakim misalnya memiliki kapasitas tentang penafsiran tersebut dalam sebuah persidangan. Maka keadaan pasal-pasal seperti itu sangat memungkinkan menjadikan sebuah penafsiran hukum menjadi pemecah masalah daripada keberagaman penfasirannya.

Atas permasalahan di atas dan juga kaitannya dengan perkembangan atau kemajuan zaman. Kemudian seiring terdapatnya permaslahan jenis baru akibat perkembangan zaman namun tidak ditemukannya hukum yang menjelaskan secara terperinci atau adanya kekosongan hukum, maka langkah atau metode penafsiran hukum sangatlah penting, bahkan menjadi suatu kewajiban untuk dilakukan. Tidak terlepas dari ranah hukum pidana, seperti contoh yang sebelumnya disebutkan di atas bahwa dalam beberapa pasal Kitab Undang-Undang Hukum Pidana (KUHP) masih terdapat penjabaran pasal yang bersifat umum.

Dengan melihat penjelasan mengenai penafsiran hukum di atas maka dapat kita pahami bahwa kata "itikad baik" pada Pasal 51 Ayat (1) KUHP tersebutlah yang perlu kita cermati lebih dalam. Sebagaimana ketentuan sebelumnya pada pasal tersebut yang menyebutkan tidak dapat dipidananya seseorang jika perbuatannya itu atas perintah jabatan atau sebagainya maka perlu kita ketahui bahwa ketentuan "tidak dapat dipidana"' itu merupakan ranah para hakim di pengadilan yang di mana konsekuensinya harus melalui tahapan pembuktian. Sebagaimana halnya perbuatan seorang pejabat yang mengatakaan bahwa tindakannya itu merupakan perintah jabatan, atau tidak terdapat perintah namun mengira tindakannya adalah masuk kategori itikad baik, maka itu semua masuk pada ranah pembuktian yang pada dasarnya berkaitan dengan penafsiran hukum.

\section{Sebab Terhapusnya Pidana Dalam KUHP}

Penjelasan tentang sebab terhapusnya pidana menjadi sangat penting, sebab dengan ini asumsi publik yang mengatakan bahwa beberapa ketentuan dalam pasal Kitab Undang-Undang Hukum Pidana merupakan asas imunitas atau kekebalan hukum bagi pejabat negara, dapat terlihat jelas pada pemaparan ini tentang benar tidaknya asumsi publik yang demikian itu. Sebagaimana halnya bahwa sebab terhapusnya pidana ini lagi-lagi masuk pada ranah pengadilan, yang di mana melalui tahapan penafsiran hukum oleh hakim, tahapan pembuktian dan lainnya. Menurut hemat penulis jika kita memahami lebih jauh ketentuan tentang sebab terhapusnya pidana pada KUHP ini maka asumsi-asumsi yang muncul sepertinya adanya anggapan terdapat asas kekebalan hukum dalam suatu perundang-undangan dapat terbantahkan melauli penerapan sebab terhapusnya pidana ini di lingkungan pengadilan yang membutuhkan waktu yang panjang dan sulit pada tahap pembuktian. 
Terdapat beberapa sebab terhapusnya pidana dalam hukum pidana yang dijadikan sebagai dasar oleh para hakim dalam menentukan putusannya terhadap para terdakwa ketika persidangan berlangsung. Sebab-sebab atau alasan tersebut disebut dalam hukum dengan sebutan penghapusan pidana. ${ }^{7}$ Adapun penghapusan pidana tersebut ditujukan bagi para majelis hakim dalam menentukan atau mempertimbangkan perkara seorang terdakwa, di mana hakim melihat pembelaannya apakah memenuhi unsur untuk penghapusan pidana. Dalam hal ini hakim menggunakan wewenangnya berdasarkan ketentuan atau pedoman perundang-undangan dengan melihat unsur-unsur tepenuhinya syarat penghapusan pidana terhadap seorang terdakwa.

Perlu dipahami mengenai penghapusan pidana ini, di mana meski seorang terdakwa telah memenuhi unsur pidana atau terbukti melakukan perbuatan tertentu namun ia tidak dipidana. ${ }^{8}$ Perlu diketahui pula bahwa penghapusan pidana ini berbeda dengan maksud penghapusan penuntutan, yang di mana penghapusan pidana sendiri dapat dilakukan oleh hakim dengan dasar bahwa perbuatan seorang terdakwa tersebut memiliki asas pembenar atau pemaaf yang terdapat dalam undang-undang terhadap apa yang telah ia lakukan. Namun meski adanya penghapusan pidana terhadap seorang terdakwa tersebut tidak menghilangkan penuntutan dari Jaksa, penuntutannya tersebut tidak hilang.

Maksudanya adalah dalam ketentuan perundang-undangan tidak melarang para Jaksa atas pengajuan seorang tersangka atau pelaku tindak pidana agar disidangkan dalam persidangan meski adanya ketentuan tentang penghapusan pidana. Oleh sebab itu para hakimlah sebagai penentu yang di mana apakah sebab maupun alasan penghapusan pidan tersebut dapat diberikan kepada seorang pelaku atau terdakwa yang ditentukan melalui vonis hakim.

Dasar atau sebab terhapusnya pidana dapat dibagi menjadi dua jenis yang dipahami secara umum, yakni (a) Alasan Pembenar, dan (b) Alasan Pemaaf. Kita dapat menemui beberapa pembahasan tentang alasan pemaaf dan alasan pembenar tersebut di beberapa literatur yang ada. Salah satunya terdapat dalam tulisan Roeslan Saleh $^{9}$. Yang menyebutkan bahwa tidak dapat dipidana seseorang terhadap apa yang telah dilakukannya karena perbuatannya tidak memenuhi unsur melawan hukum. Oleh sebab itulah hal tidak ditemukannya unsur melawan hukum tersebut dapat dijadikan sebagai sebab atau alasan pembenar. Suatu perbuatan yang semula dinilai sebagai perbuatan yang tidak baik atau keliru, namun bisa saja dalam pandangan lain perbuatan tersebut sudah sesuai atau dapat dibenarkan.

Adapun penghapusan pidana tersebut berlaku bagi pelaku atau terdakwa (orang/subjek), yang di mana dapat juga untuk dipergunakan sebagai penghapusan pidana terhadap sifat atau bentuk suatu perbuatan atau tingkah laku tersebut yang dalam hal ini merupakan (objek). Berkaitan dengan hal itu, adapun sebab atau alasan

\footnotetext{
7 Hamdan, Hukum Pidana Materil dan Formil dalam Alasan Penghapusan Pidana, UNSAD: Partnership, 2015, hlm. 286.

${ }^{8}$ Sofyan, Hukum Pidana, Cet-1 C.V, Bandung: 1990, hlm. 223.

${ }^{9}$ Roeslan, Perbuatan Pidana dan Pertanggung Jawabannya, Jakarta: 1983, hlm. 125.
} 
terhadap penghapusan pidana dapat kita klasifikasikan diantara, tidak dapatnya dipidana seorang atau pelaku/terdakwa seiring tidak dapatnya dipidana atas perbuatannya tersebut. Maka dalam hal inilah maksud yang disebutkan di atas tersebut, sebagaimana yang berkaitan antara subjek dan objek terhadap tindakan pengahapusan pidana tersebut. Dalam hal ini baik pelaku/terdakwa maupun perbuatannya tersebut dapat dihapus tindak pidananya selama memenuhi unsurunsur atau ketentuan penghapusan pidana yang termuat dalam perundang-undangan.

Namun pada tulisan kali ini akan membahas tentang bagaimana konsep tentang penghapusan pidana tersebut dari alasan pembenar tanpa menjelaskan penghapusan pidana dari alasan pemaaf.

Alasan pembenar dapat diartikan atau dipahami dengan sebuah makna bahwa suatu alasan dalam meniadakan sifat melawan hukum terhadap suatu tindakan atau perbuatan yang dilakukan oleh seseorang. Oleh sebab itu tindakan yang dilakukan seseorang tersebut dapat dikatakan bebas dan tidak dijatuhi pidana. ${ }^{10}$ Dalam beberapa literatur atau pedoman dalam perundang-undangan yang ada, adapun alasan penghapusan pidana yang merupakan bagian terhadap alasan pembenar itu sendiri. Seperti dalam ketentuan Kitab Undang-Undang Hukum Pidana (KUHP) sebagai berikut:

a. Penghapusan Pidana Akibat Adanya Keadaan Darurat Pasal 48 KUHP

Banyak perdebatan mengenai perbuatan mana saja yang termasuk dalam keadaan darurat, beberapa waktu yang lalu perdebatan tentang makna hal darurat tersebut terjadi ketika adanya dua kasus tindak pidana yang sekilas mirip. Kasus yang pertama ialah dua orang pemuda yang melawan aksi pembegalan ketika ia di todong dengan sebuah celurit (senjata tajam) di Jembatan Layang Sumarecon Bekasi, yang di mana dua pemuda tersebut mampu melawan dengan merebut senjata tajam dan melumpuhkan pelaku pembegalan tersebut.

Maka dalam hal ini sebagian pakar hukum ataupun aparat penegak hukum mengatakan bahwa kejadian tersebut merupakan keadaan darurat, sebagaimana jika dua pemuda tersebut tidak melakukan perlawanan maka bisa jadi dirinya akan terluka dan bisa saja terbunuh. Namun terdapat pendapat lain bahwa, perlawanan tersebut tidak seharusnya sampai menghilangkan nyawa, namun perlu diketahui dalam keadaan mencekam seperti itu maka sesuatu yang tidak kita inginkan bisa saja terjadi. Oleh sebab itu, maka bisa saja kasus tersebut masuk kedalam keadaan darurat.

Kemudian kasus yang kedua dialami oleh seorang pelajar yang membunuh begal karena membela sang pacar yang hendak diperkosa, yang di mana dalam hal ini pihak kepolisian tidak dapat memasukkan kasus ini sebagai tindakan atau dalam keadaan darurat, malah justru pelajar tersebut didakwa oleh hakim dengan Pasal 340 KUHP tentang Pembunuhan Berencana. Karena sebagaimana diketahui bahwa pelajar tersebut dengan sengaja menaruh atau

${ }^{10}$ Sofyan, Hukum Pidana, Cet-1 C.V, Bandung: 1990, hlm. 225. 
membawa senjata tajam di jok motornya, yang seketika itu digunakan untuk melawan pelaku pembegalan. Meski dalam persidangan pembelaan terjadi dari kuasa hukumnya dengan berasumsi bahwa dakwaan Pasal 340 KUHP tersebut tidak sesuai karena pelajar tersebut tidak melakukan rencana pembunuhan. Hanya saja senjata tajam yang dibawa tersebut semata-mata untuk jaga diri. Namun meski pembelaan tersebut dilakukan kasus ini menurut majelis hakim tidak dapat dikatakan sebagai keadaan darurat.

Dari kedua kasus di atas, dapat memberikan pemahaman kepada kita semua bahwa maksud daripada keadaan darurat tersebut tidak bisa dengan sembarang kita sebut bahwa suatu tindakan kita masuk sebagai tindakan darurat. Ini berkaitan pula dengan penafsiran hukum yang sebelumnya telah dijelaskan di atas.

b. Penghapusan Pidana Terhadap Pembelaan Terpaksa Pasal 49 Ayat (1) KUHP

Sebagaimana telah disebutkan di atas terhadap tindakan perlawanan pelaku begal, dan juga dalam hal ini memiliki keterkaitan dengan penafsiran hukum. Disebutkan dalam Pasal 49 Ayat (1) KUHP bahwa tindakan yang dapat dikategorikan sebagai pembelaan terpaksa harus memenuhi unsur; Pertama, Terdapat serangan mendadak yang dapat mengancam diri kita; Kedua, Serangan tersebut dapat dikatakan sebagai tindakan melawan hukum; dan Ketiga, Pembelaan tersebut patut dilakukan karena sudah sangat mengancam diri kita.

Untuk menganalisa terhadap suatu tindakan pembelaan terpaksa tersebut agar dapat terbebas dari tindak pidana maka perlu dilihat terhadap adanya asas keseimbangan ataupun asas proporsionalitas dan asas subsidaritas. Asas proporsionalitas dapat diartikan sebagai suatu pembelaan yang setimpal atau yang sebanding dengan sebuah serangan. Jika melihat kedua kasus yang disbutkan di atas maka dapat kita menganlisanya bahwa pada kasus yang pertama dua orang pemuda tersebut diancam menggunakan celurit dan ketika pembegalan tersebut terjadi baik kedua pemuda dan pelaku pembegalan samasama melakukan perlawanan, di mana dalam hal ini kedua pemuda dengan terpaksa melakukan perlawanan karena adanya ancaman. Hal ini juga memenuhi unsur dari ketiga kategori dapat dikatakannya suatu pembelaan terpaksa menurut Pasal 49 KUHP yang disebutkan di atas.

Sedangkan jika menganalisa kasus yang kedua di atas bahwa meski pada dasarnya tindakan pembelaan seorang remaja tersebut ketika pacarnya hendak diperkosa, yang di mana memenuhi unsur beberapa kategori pembelaan terpaksa, seperti kejadian akan terjadinya pemerkosaan tersebut merupakan tindakan melawan hukum. Namun meski demikian perlunya melihat unsur lainnya seperti kejadian pembegalan tersebut apakah sudah mengancam diri (nyawa) pelajar tersebut atau tidak, ataukan sudah termasuk sebagai tindakan perlawanan keras semacam adanya ancaman menggunakan senjata dan sebagainya. 
Maka perlu dilihat juga terhadap asas proporsionalitasnya, bahwa dalam kasus yang kedua tersebut sebagaimana perlawanan terhadap begal dengan membunuhnya yang di mana sebelumnya pelaku begal tersebut tidak melakukan pengancaman diri (nyawa) terhadap remaja tersebut, yang hanya akan memperkosa sang pacar. Yang di mana hal tersebut apakah dapat dikatakan sebagai tindakan pembelaan terpaksa atau tidak. Tentu lagi-lagi hal ini berkaitan dengan metode penafsiran hukum yang dilakukan oleh hakim pada saat persidangan berlangsung yang menyebutkan remaja tersebut terbukti bersalah yang kemudian didakwa dengan Pasal 340 KUHP tentang Pembunuhan Berencana, karena kalau kita melihat asas proporsionalitasnya dapat kita katakan bahwa tindakan pelajar tersebut bisa saja masuk sebagai tindakan yang berlebihan dan pembelaannya itu tidak sebanding dengan ancaman yang ia dapat.

c. Penghapusan Pidana Karena Menjalankan Perintah Undang-Undang Pasal 50 KUHP

Suatu perbuatan atau tindakan menjalankan perintah perundangundangan telah disebutkan dalam Pasal 50 KUHP yang menyebutkan bahwa seseorang yang melakukan sesuatu tindakan dengan ketentuan melaksanakan perintah atau ketentuan undang-undang terhadap sesuatu tindakannya itu, maka seseorang tersebut tidak dapat dipidana. Namun terdapat beberapa hal yang perlu dipahami terhadap ketentuan penghapusan pidana yang disebutkan dalam Pasal 50 KUHP tersebut diantaranya:

1) Suatu ketentuan perundang-undangan terhadap semua peraturan yang dibuat oleh penguasa yang berwenang terhadap maksud tertentu yang mana disebutkan dalam undang-undang.

2) Perbuatan yang di mana jika tidak disebutkan perintahnya dalam peraturan perundang-undangan, maka tindakan atau perbuatan tersebut termasuk tindak pidana, dan sebaliknya yang dibenarkan ialah suatu perintah atas wewenang penguasa yang disebutkan dalam perundang-undangan, maka hal itu dapat dibenarkan.

d. Penghapusan Pidana Karena Menjalankan Perintah Jabatan Pasal 51 KUHP

Disebutkan dalam Pasal 51 Ayat (1) bahwa jika seseoarang melakukan suatu tindakan atau perbuatan yang di mana perbuatannya tersebut dalam rangka melaksanakan perintah jabatan yang diberikan oleh penguasa yang berwenag atau memiliki kapasitas terhadap perintah tersebut, maka seseorang yang melakukan perintah tersebut tidak dapat dipidana.

Adapun berbedaan yang mendasar terhadap melakukan suatu perintah berdasarkan perundang-undangan dengan suatu perintah atas perintah atau instruksi jabatan yang berwenang adalah suatu perintah jabatan memiliki suatu hubungan antara seseorang yang diberikan perintah dan seseorang yang memiliki jabatan atas wewenangnya dalam memberikan perintah, atau dengan kata lain adanya hubungan publik. Yang di mana perintah atas wewenang 
jabatan tersebut juga harus berdasarkan peraturan perundang-undangan. Sedangkan menjalankan perintah undang-undang sudah jelas bahwa akan menjadi benar terhadap apa yang akan kita perbuat ketika hal tersebut diamanatkan oleh undang-undang yang ada.

Sebagai gambaran apa yang dimaksud sebagai perintah jabatan adalah, antara Presiden dan Menteri yang di mana kedua jabatan tersebut memiliki hubungan publik. Akibat adanya hubungan publik antara Presiden dan Menteri tersebut, maka seorang menteri dapat dibenarkan melakukan sesuatu tindakan atas perintah seorang presiden yang di mana perintah presiden tersebut sejauh kapasitas atau wewenangnya yang disebutkan dalam perundang-undangan.

e. Penghapusan Pidana Karena Menjalankan Perintah Jabatan Yang Tidak Sah (Adanya Unsur Itikad Baik Pasal 51 Ayat (2) KUHP)

Disebutkan dalam Pasal 51 Ayat (2) bahwa suatu perintah jabatan tanpa wewenang atau kapasitasnya, maka hal tersebut tidak dapat dijadikan sebagai pembelaan atau penghapusan pidana, namun dengan pengecualian bahwa apa yang dialakukan oleh seseorang tersebut dengan unsur itikad baik yang mana perbuatan seseorang tersebut juga termasuk dalam ruang lingkup pekerjaannya. Perlu dipahami bahwa seseorang yang melakukan tindakan dengan perintah jabatan yang tidak sah bersifat melawan hukum, namun meski demikian ia bisa saja bebas dari pidana jika telah memenuhi unsur-unsur yang diantaranya:

Pertama, Seseorang yang menjalankan perintah dengan itikad baik dan ia mengira bahwa perintah tersebut akan menjadi sah diberikan oleh perintah jabatan yang berwenang; ${ }^{11}$ dan Kedua, Dalam melaksanakan suatu tindakan seseorang tersebut melakukan tindakan atau perbuatan yang mana dalam ruang lingkup perkerjaanya. Dalam hal ini dapat juga dilihat terhadap terpenuhinya syarat subjektif dan syarat objektif:

\section{1) Syarat Subjektif}

Syarat subjektif ini terdapat pada masing-masing individu seseorang atau dalam hal ini berkaitan dengan batin seseorang yang menerima suatu perintah. Kenapa demikian, bahwa perlu kita pahami manusia sebagai mahluk yang memiliki akal pikiran yang mampu membedakan mana yang benar dan salah, mana yang baik dan juga buruk, oleh sebab itulah hal-hal bersifat masuk akal perlu ditekankan dalam hal ini.

Sebagai contoh seorang sekretaris desa melakukan suatu perbuatan yang mana ia mengira bahwa pada dasarnya apa yang akan ia perbuat nantinya juga akan diperintahkan oleh sang kepala desa. Maka dalam hal ini sesuatu yang rasional dan masuk akal sudah terpenuhi. Berbeda halnya jika

${ }^{11}$ Ibid, hlm, 245. 
seorang sekretaris desa akan melakukan sesuatu yang mana ia mengira bahwa perintah tersebut merupakan perintah bupati maka dalam hal ini tidak ditemukan kerasionalannya, karena perbuatan tersebut jauh dari lingkup pekerjaan sang sekrertaris desa.

2) Syarat Objektif

Syarat objektif ini adalah berkaitan dengan pembahasan sebelumnya antara pemberi perintah dan penerima perintah memiliki hubungan publik, seperti di contohkan sebelumnya di atas antara Presiden dan para Menterinya, kedua jenis jabatan tersebut memiliki hubungan publik sebagai pejabat negara. Maka dalam hal ini perintah yang diberikan kepada seseorang harus masuk lingkup hubungan publik antara suatu jabatan.

Dari penjelasan mengenai sebab terhapusnya pidana di atas menurut hemat penulis bahwa yang perlu kita pahami adalah, adanya tahapan panjang dalam ranah pembuktian terhadap dugaan tindak pidana baik yang dilakukan oleh pejabat negara ataupun masyarakat pada umumnya. Dalam hal ini tidak terlepas pada tahapan penafsiran atau pembuktian pada ketentuan Pasal 50, 51 Ayat (1) dan (2) KUHP.

\section{Penutup}

Dapat kita pahami bahwa hukum pidana merupakan bagian dalam bidang ilmu hukum. Hukum pidana dapat dilihat dari segi prakteknya yang di mana ketentuan yang melekat pada hukum pidana adalah adanya pemberian ancaman atau sanksi bagi seseorang yang melakukan suatu tindakan yang dilarang yang sebelumnya disebutkan dalam peraturan hukum yang dibuat. Berkaitan dengan ketentuan hak imunitas pada dasarnya tidak disebutkan dalam peraturan manapun khususnya pada Kitab UndangUndang Hukum Pidana. Adanya asumsi publik terhadap keberadaan Pasal 50, 51 Ayat (1) dan (2) KUHP sebagai dasar imunitas atau kekebalan hukum bagi seorang pejabat muncul karena permasalahan dari segi pemaknaan atau penafsiran redaksi bahasa pada pasal dalam KUHP tersebut. Pada prinsipnya ketentuan Pasal 50, 51 Ayat (1) dan (2) KUHP perlu penafsiran yang mendalam mecangkup ranah penafsiran oleh hakim dalam pengadilan, dan adanya tahapan pembuktian terhadap penggunaan pasal tersebut ketika dijadikan sebagai asas pembelaan oleh seorang terduga melakukan tindak pidana. Meski memang tidak menutup kemungkinan bahwa dalam beberapa ketentuan pada KUHP seperti yang terdapat pada Pasal 48 tentang terhapusnya pidana akibat adanya keadaan darurat, Pasal 49 tentang pembelaan terpaksa, dan Pasal 50, 51Ayat (1) dan (2) adalah semata-mata sebagai alasan pembenar dan pemaaf dalam ketentuan hukum pidana dengan tujuan untuk menghindari menghukum atau menjatuhkan pidana pada seseorang yang tidak bersalah. Namun bukan berarti ketentuan-ketentuan dalam beberapa pasal KUHP tersebut merupakan asas imunitas atau kekebalan hukum bagi pejabat negara. 


\section{Daftar Pustaka}

\section{Buku}

Farid Abidin Andi Zainal, Hukum Pidana, Cet-1, Jakarta: Sinar Grafika, 1995

Hamdan, Hukum Pidana Materil dan Formil, USAID, Partnership, 2015

Hiariej Eddy O.S., Asas Legalitas dan Penemuan Hukum Pidana, Jakarta: Erlangga, 2009

Marzuki Peter, Penelitian Hukum, Jakarta: Prenada Media Group, 2015

Roeslan, Perbuatan Pidana dan Pertanggung Jawaban Pidana, Jakarta: Aksara Baru, 1983

Setyo Deni, Asas Legalitas Hukum Pidana, Setara Pers, 2014.

Soerjono, Pengantar Penelitian Hukum, Jakarta: UI Pers, 1984

Sofyan Andi dan Aziza Nur, Hukum Pidana, Makasar: Pustaka Pena Pers, 2016

Sofyan, Hukum Pidana, Cet-1 C.V, Bandung, 1990

Surya Ida Bagus, Hukum Pidana Materil dan Formil: Pengantar Hukum Pidana, Denpasar: Udayana University Press, 2015

\section{Peraturan Perundang-Undangan:}

Buku Ajar Hukum Pidana Fakultas Hukum Universitas Udayana (Buku Ajar Tahun 2016).

Kitab Undang-Undang Hukum Pidana KUHP (Buku Kesatu Aturan Umum).

Undang-Undang Republik Indonesia Nomor 1 Tahun 1946 tentang Peraturan Hukum Pidana (Lembaran Negara Republik Indonesia Tahun 1946).

\section{Internet:}

Maya Septiani, "Oentarto Mengaku Hanya Jalankan Perintah Jabatan ,',https://m.hukumonline.com/ berita/ baca/lt4b2f77e45c445/ oentartomengaku- hanya-jalankan-perintah-jabatan/. akses 16 Juni 2020.

Atang Irawan, Hak Imunitas Pejabat Negara, https://rmol.id/amp. 2020/05/01/ 432808/ https-rmol-id-read-2020-05-01-43 2808-hak-imunitas-prjabatnegara. akses 26 November 2020. 